\title{
Xylanase Production by a Thermo-tolerant Bacillus Species under Solid-state and Submerged Fermentation
}

\author{
Uma Gupta and Rita Kar* \\ Department of Biochemical Engineering and Food Technology; Harcourt Butler Technological Institute; Kanpur- \\ 208002 - India
}

\begin{abstract}
Effects of xylose on xylanase production by a thermophilic Bacillus sp showed diverse patterns on corn cob (CC) and wheat bran $(W B)$ as sole carbon sources in solid-state fermentation (SSF) and submerged fermentation (SmF). Supplementation of these media with either mineral salt solution (MSS) or yeast extract peptone (YEP) also exerted variable effects. While under SSF, xylose stimulated xylanase synthesis by $44.01 \%$, on wheat bran supplemented with MSS, it decreased the enzyme activity by $12.89 \%$ with YEP supplementation. In SmF, however the enzyme synthesis was stimulated by xylose on supplementation with both MSS and YEP by $41.38 \%$ and $27.47 \%$, respectively. On corn cob under SSF, xylose repression was significant both with MSS (26.92\%) and YEP (23.90\%) supplementation. Repression by xylose also took place on corn cob and YEP (19.69\%) under SmF, while significant stimulation (28.55\%) was observed by MSS supplementation. The possible role of media composition and fermentation conditions in the regulation of xylanase synthesis by xylose is discussed.
\end{abstract}

Key words: Xylanase production, thermo-tolerant Bacillus species, xylose induction and repression, corn cob, wheat bran, solid- state and submerged fermentation

\section{INTRODUCTION}

Xylanases (E.C.3.2.1.8) are inducible enzymes which are responsible for complete hydrolysis of xylan, the major component of the hemicellulosic complex found in the plant cell wall. As xylan is the most abundant renewable polysaccharide after cellulose, its hydrolysis by xylanases into simpler compounds, mainly xylose, is important for several biotechnological applications. Currently the most important application of xylanases is in prebleaching of kraft pulps to minimize the use of harsh chemicals in the subsequent treatment stages of kraft pulp. Apart from its use in pulp and paper industry, xylanases are also used in baking for improving bread quality by increasing specific bread volume, for must and juice clarification and for liquefying the fruits and vegetables along with pectinases and cellulases.

For the production of any industrial enzyme, an inexpensive substrate and an efficient fermentation process are essential for commercial viability. It has been established that solid-state fermentation (SSF) has several advantages over submerged fermentation $(\mathrm{SmF})$, due to smaller volume of solvent required for product recovery, resulting in higher productivity per unit volume, lower contamination and foaming problems and better exploitation of various agro-residues as substrates (Nigam and Singh, 1994; Grajek, 1987; Archana

\footnotetext{
*Author for correspondence: rkarhbti@ rediffmail.com
} 
and Satyanarayan, 1997; Kewalrami et al., 1988). Hence, xylanase production using xylan rich agroresidues such as wheat bran, eucalyptus kraft pulp, wheat straw, rice bran, rice straw, sugarcane bagasse and corn cob has been attempted by several workers using fungi (Qinnghe et al., 2004; Bakir et al., 2001; Anthony et al., 2003; Singh et al., 2000), bacteria (Archana and Satyanarayan, 1997; Bataillon et al., 1998; Virupakshi et al., 2005), actinomycetes (Kohli et al., 2001; Beg et al., 2002; Nascimento et al., 2002) and yeasts (Liu et al., 1999). As corn cob is a rich source of both xylan (28\%) and xylose (23\%), it is potentially an ideal substrate for xylanase production, but reports on utilization of corn cob are limited. This is perhaps due to lower yields observed on corn cob compared to other substrates by some workers (Qinnghe et al., 2004; Nascimento et al., 2002). Hence, further studies on various aspects of corn cob utilization for improved xylanase yields may prove to be beneficial.

As xylanases are inducible enzymes, various studies on their induction and repression have been reported. Most of these studies include the effects of inducers and repressers such as xylan, xylose, arabinose, glucose, maltose, galactose and other similar compounds (Anthony et al., 2003; Kohli et al., 2001; Liu et al., 1999; Leathers et al., 1986; Paul and Verma, 1990; Xiong et al., 2004). But none of these studies aimed at the evaluation of induction and repression effects of these substances with respect to medium composition or fermentation conditions. The aim of this work was therefore to evaluate and compare the induction and repression effects of xylose on xylanase synthesis using corn cob and wheat bran as sole C sources, supplemented with either mineral salt solution (MSS) or a mixture of yeast extract and peptone (YEP) under SSF and SmF. These studies were performed with a thermophilic xylanolytic bacterial species producing thermo-stable xylanase (optimum temp $55^{\circ} \mathrm{C}$ ), as thermo-stable xylanases are more relevant for industrial application (Kohli et al., 2001; Nascimento et al., 2002), and also as xylanase production by thermophilic bacteria under SSF using corn cob has not been reported.

\section{MATERIALS AND METHODS}

\section{Materials}

Oat spelt xylan (Himedia Labroratories Pvt. Ltd., India) was used for enzyme assay. Wheat bran was procured from a local market and sieved $(0.5 \mathrm{~mm}$. particle size). Corn cob was prepared by stripping corn of all the kernels, drying, grinding and sieving $(0.5 \mathrm{~mm}$. particle size $)$.

\section{Microbial Strain}

The bacterial strain used in this study was isolated from decayed woody materials. This strain was identified as Bacillus licheniformis by MTCC, Chandigarh with the accession number MTCC 9415. The optimum growth temperature of this strain was $45^{\circ} \mathrm{C}$.

\section{Inoculum Preparartion}

The culture was maintained on corn cob, yeast extract, peptone, agar stants $(4: 1: 1: 3 \% \mathrm{w} / \mathrm{v})$, stored at $4^{0} \mathrm{C}$ and subcultured routinely after every threefour weeks. For inoculum preparation the culture was grown at $45^{\circ} \mathrm{C}$ for $72 \mathrm{~h}$ and was used to inoculate $50 \mathrm{ml}$ of fermentation medium.

\section{Xylanase production in SSF}

\section{Mineral Salt Medium}

Erlenmeyer flasks containing $10 \mathrm{~g}$ of wheat bran/corn cob and $35 \mathrm{ml}$ of mineral salt solution (MSS) g/l : $\mathrm{MgCl}_{2} .6 \mathrm{H}_{2} \mathrm{O}, 6.6 ; \mathrm{K}_{2} \mathrm{HPO}_{4}, 0.5$; $\mathrm{KH}_{2} \mathrm{PO}_{4}, 0.5 ; \quad\left(\mathrm{NH}_{4}\right)_{2} \mathrm{SO}_{4}, 2.0 \mathrm{~g} ; \mathrm{pH}$ 6.7) were autoclaved for $20 \mathrm{~min}$ at 15 p.s.i., cooled, inoculated with $10 \%(\mathrm{v} / \mathrm{w})$ of inoculum $(24 \mathrm{~h}$ old $)$ and incubated at $45^{\circ} \mathrm{C}$. At the desired intervals, the flasks were removed and the contents extracted were with $50 \mathrm{ml}$ of $0.02 \mathrm{M}$ phosphate buffer $(\mathrm{pH}$ 7.0).

\section{Yeast Extract Peptone Medium}

Wheat bran/ corn cob (10g) and $35 \mathrm{ml}$ of YEP solution containing $(\mathrm{g} / \mathrm{l})$ : yeast extract, 10.0; peptone, 10.0 was taken in place of MSS and all the other procedures as mentioned above were followed.

\section{Effect of xylose on xylanase synthesis}

To observe the effect of xylose, $1 \%(w / v)$ xylose was added into both the above media.

\section{Enzyme extraction}

Enzyme was extracted with $50 \mathrm{ml} \quad 0.02 \mathrm{M}$ phosphate buffer (pH 7.0) and squeezed through a wet muslin cloth. The enzyme extracted was centrifuged at $1500 \mathrm{rpm}$ for $30 \mathrm{~min}$. The clear supernatant was used in the enzyme assay. 


\section{Xylanase production in $\mathrm{SmF}$}

Erlenmeyer flasks $(250 \mathrm{ml})$ containing $50 \mathrm{ml}$ of medium containing 4\% (w/v) wheat bran/ corn cob and either MSS or YEP as described above were inoculated with $10 \%(\mathrm{v} / \mathrm{v})$ inoculum and incubated at $45^{\circ} \mathrm{C}$ on a rotary shaker at $130 \mathrm{rpm}$. Aliquots were withdrawn at appropriate intervals and analysed for enzyme activity and biomass after filtering out the substrate particles.

\section{Enzyme and Biomass Assay}

Xylanase activity was measured by incubating $0.5 \mathrm{ml}$ of $0.4 \%(\mathrm{w} / \mathrm{v})$ oat spelt xylan in $0.02 \mathrm{M}$ phosphate buffer $(\mathrm{pH} 7.0)$ and $0.5 \mathrm{ml}$ of suitably diluted enzyme extract at $45{ }^{\circ} \mathrm{C}$ for $30 \mathrm{~min}$. The release of reducing sugar was measured as xylose by dinitro salicylic acid method (Miller, 1959). One unit (U) of xylanase is defined as the amount of enzyme that release $1 \mu \mathrm{mol}$ xylose $/ \mathrm{ml} / \mathrm{min}$ under the assay conditions.

Biomass was determined as dry weight in $\mathrm{mg} / \mathrm{ml}$ from a calibration graph of optical density versus dry weight.

All the experiments were carried out in triplicates. The analyses were done in duplicates. The mean values are shown in the figures and tables.

\section{RESULTS AND DISCUSSION}

Xylanases are inducible enzymes and a number of inducers of the enzyme have been studied among which xylan and xylose are the most widely reported. The effect of the inducers on xylanase production with respect to different media and in varying fermentation conditions are however not well established. The effects of supplements such as mineral salts (MSS) and organic cell extracts such as yeast extract and peptone, and xylose as inducer, along with agro residues such as corn cob and wheat bran as carbon sources on xylanase production by the Bacillus sp under SSF and SmF were found to exert diverse effects.

\section{Xylanase and biomass Production in $\mathrm{SmF}$}

\section{On wheat bran and MSS medium}

On wheat bran supplemented with MSS in SmF, the Bacillus sp. produced maximum xylanase activity of $9.11 \mathrm{U} / \mathrm{ml}$ in $48 \mathrm{~h}$ (Fig. 1). The biomass was also maximum with $1.6 \mathrm{mg} / \mathrm{ml}$ (dry weight basis) after $48 \mathrm{~h}$ (Fig. 1). Addition of $1 \%$ xylose increase both the enzyme activity and biomass to $12.88 \mathrm{U} / \mathrm{ml}$ and $1.8 \mathrm{mg} / \mathrm{ml}$ respectively (Figs. 1 and 2). Xylanase stimulation by xylose has been reported in bacteria and fungi (Bataillon et al., 1998; Leathers et al., 1986) and is generally considered as an inducer of the enzyme. Supplementation of wheat bran with a mineral salt solution has also been employed for a Streptomyces sp which produced $28.4 \mathrm{U} / \mathrm{ml}$ xylanase in submerged condition in 10 days (Nascimento et al., 2002).

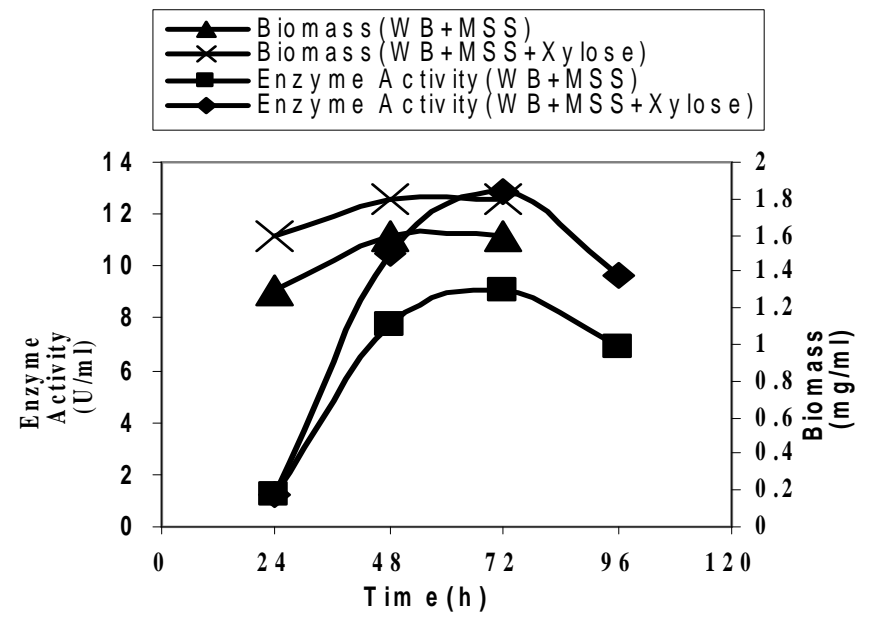

Figure 1- Effect of xylose on xylanase production and biomass production by the Bacillus sp on wheat bran supplemented with mineral salt solution (MSS) by SmF. 


\section{On corn cob and MSS medium}

Fig. 2 shows xylanase activity and biomass produced by the bacteria under similar conditions with corn cob as a substrate. In this case also $1.0 \%$ xylose addition stimulated xylanase activity from 7.11 to $9.14 \mathrm{U} / \mathrm{ml}$ and biomass from 1.0 to 1.25 $\mathrm{mg} / \mathrm{ml}$. The maximum enzyme activity and biomass however could be obtained after $72 \mathrm{~h}$, suggesting that corn cob supported lesser and slower growth and enzyme synthesis compared to wheat bran. Similar reduction in xylanase activity has been reported on corn cob $(9.11 \mathrm{U} / \mathrm{ml})$ compared to wheat bran $(28.4 \mathrm{U} / \mathrm{ml})$ in Streptomyces (Nascimento et al., 2002) and fungal (Qinnghe et al., 2004) sp.

\section{On wheat bran and YEP medium}

When salt solution was replaced by $1.0 \%$ YEP in wheat bran medium under $\mathrm{SmF}$, the bacterial growth was higher and faster than the former both in the absence and presence of xylose, while the xylanase activity was lower (Fig. 3). Moreover, the exponential growth was over within $24 \mathrm{~h}$ followed by a static phase of about $8 \mathrm{~h}$ and then a diauxic growth spanning about $16 \mathrm{~h}$. The biomass values obtained were 1.1 and $0.9 \mathrm{mg} / \mathrm{ml}$ after first exponential growth phase $(24 \mathrm{~h})$ with and without xylose, respectively, which attained the values of 2.0 and $1.7 \mathrm{mg} / \mathrm{ml}$ during diauxic growth in $48 \mathrm{~h}$ (Fig. 3).

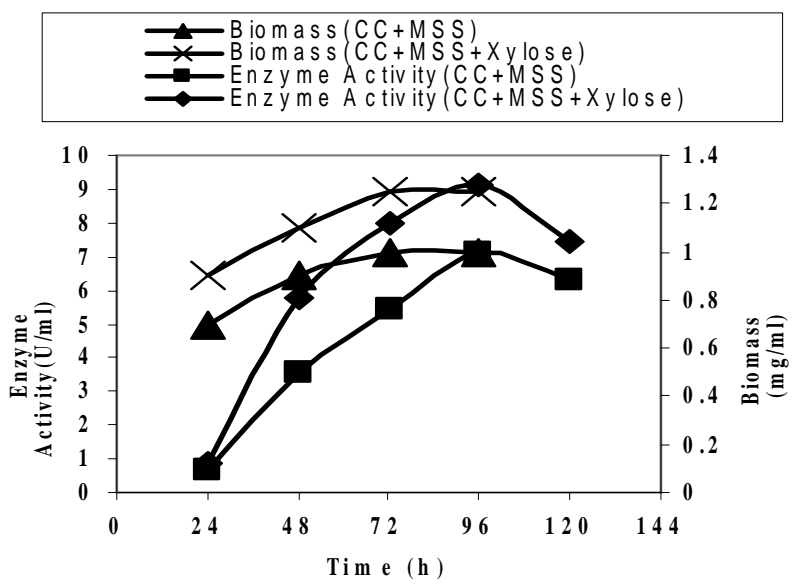

Figure 2 - Effect of xylose on xylanase production and biomass production by the Bacillus sp on corn cob supplemented with MSS by SmF.

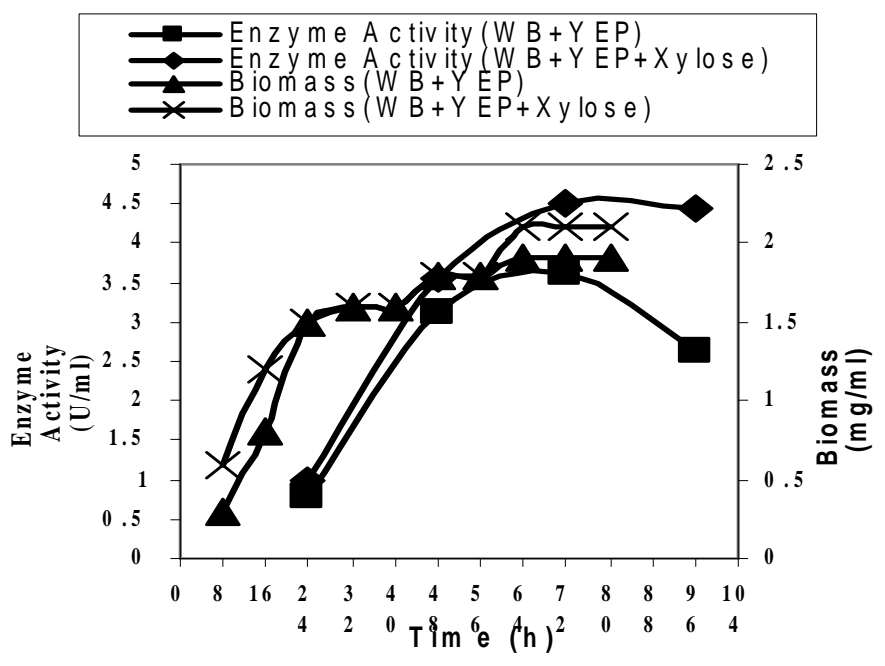

Figure 3 - Effect of xylose on xylanase production and biomass production by the Bacillus sp on wheat bran supplemented with yeast extract and peptone (YEP) by SmF. 
It was interesting to note that maximum enzyme activity was obtained in these cases when the biomass reached the peak value in $48 \mathrm{~h}$, after the second phase of diauxic growth. The maximum enzyme activities were 8.77 and $6.88 \mathrm{U} / \mathrm{ml}$ with and without xylose respectively in 48 h (Fig. 3). These values were lower than the corresponding maximum values of 9.11 and $12.88 \mathrm{U} / \mathrm{ml}$ obtained with MSS as supplements (Table 1). Supplementation of agro-residues with cell extracts for xylanase production by Bacillus - SPS$\mathrm{O}$ sp. has been reported to produce xylanase activity of $50 \mathrm{nkat} / \mathrm{ml}$ on wheat bran arabinoxylan supplemented with yeast extract $1 \%$ and tryptone $1 \%$ in $24 \mathrm{~h}$ in submerged condition, and xylose acted as an inducer (Bataillon et al., 1998). Another Bacillus sp produced maximum enzyme of $51 \mathrm{U} / \mathrm{ml}$ in $48 \mathrm{~h}$ on rice husk in nutrient broth by submerged fermentation (Paul and Verma, 1990).

Although YEP enhanced biomass production by the bacteria compared to MSS, yet enzyme synthesis was repressed. This happened in spite of the fact that xylanase synthesis has been reported to be growth associated by most authors (Santos et al., 2003; Bachmann and McCarthy, 1991; Trigo and Ball, 1994; Fernandez et al., 1995). As TCA cycle promotes biomass formation, hence, it is likely that higher activity of the TCA cycle enzymes decreases xylan utilization, hence, xylan synthesis, while, stimulating growth, utilizing $\mathrm{C}$ sources of wheat bran other than xylan.

\section{On corn cob and YEP medium}

When corn cob was supplemented with YEP, similar stimulation in growth of the bacteria and diauxic behaviour were observed. The maximum biomass and xylanase activity of $1.9 \mathrm{mg} / \mathrm{ml}$ and $3.63 \mathrm{U} / \mathrm{ml}$ with xylose and $2.1 \mathrm{mg} / \mathrm{ml}$ and 4.52 $\mathrm{U} / \mathrm{ml}$ without xylose were obtained in $48 \mathrm{~h}$ (Fig. 4).

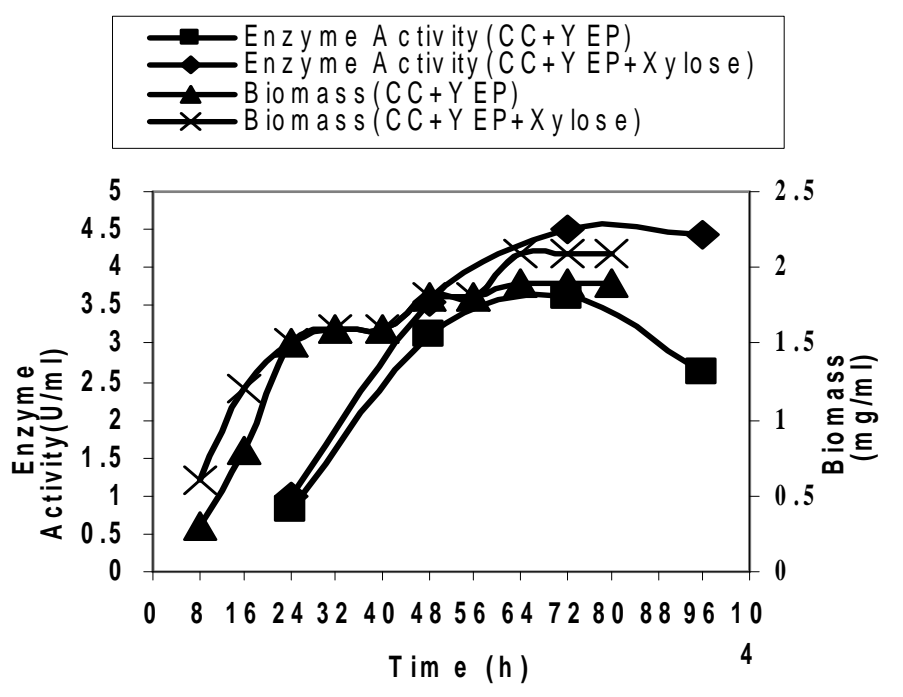

Figure 4 - Effect of xylose on xylanase production and biomass production by the Bacillus sp on corn cob supplemented with yeast extract and peptone (YEP) by SmF.

In the presence of YEP on wheat bran and corn cob, first exponential growth phases were completed in $24 \mathrm{~h}$, resulting in sufficient growth but not much enzyme activity. In the diauxic growth phase, the enzyme activity reached the peak values (Fig. 4).

This could due to the fact that during the diauxic growth, xylanase synthesis was stimulated, when xylan and xylose provided the $\mathrm{C}$ source. Although the biomass on corn cob was slightly higher with YEP compared to MSS, enzyme activities were lower with YEP (3.63 and $4.52 \mathrm{U} / \mathrm{ml}$, with and without xylose) than MSS supplementation values (9.14 and $7.11 \mathrm{U} / \mathrm{ml}$, with and without xylose) (Table 1). 
Table 1 - Comparative values of the xylanase and biomass production by Bacillus sp on wheat bran and corn cob by SmF.

\begin{tabular}{|c|c|c|c|c|}
\hline $\begin{array}{l}\text { Medium } \\
\text { composition }\end{array}$ & $\begin{array}{c}\text { Xylanase activity } \\
\text { (U/ml) }\end{array}$ & With xylose & $\begin{array}{c}\begin{array}{c}\text { Biomass } \\
(\mathrm{mg} / \mathrm{ml})\end{array} \\
\text { Without xylose } \\
\end{array}$ & With xylose \\
\hline WB + MSS & 9.11 & 12.88 & 1.6 & 1.8 \\
\hline WB + YEP & 6.88 & 8.77 & 1.7 & 2.0 \\
\hline $\mathrm{CC}+\mathrm{MSS}$ & 7.11 & 9.14 & 1.0 & 1.25 \\
\hline $\mathrm{CC}+\mathrm{YEP}$ & 4.52 & 3.63 & 2.0 & 1.90 \\
\hline
\end{tabular}

*The maximum values obtained are indicated.

Thus the pattern obtained with YEP supplementation in corn cob, where xylose brought about a reduction in enzyme and biomass synthesis by the Bacillus strain, was reverse of all other observations, when xylose acted as a stimulator (Figs. 1-3). Xylose addition resulting in lower growth and enzyme yield was perhaps due to the repression of the enzyme synthesis by feed back inhibition, as a result of xylan degradation, which also produced xylose additionally. Catabolite repression by xylose in the course of xylan (from corn cob) degradation could also be distinct possibility. Catabolite repression by xylose has been established by various reports (Archana and Satnarayanan, 1997; Lemos and Junior, 2002). Corn cob itself has much higher contents of xylose and xylan compared to wheat bran. It can be noted that both in wheat bran and corn cob media, YEP supplementation in place of MSS resulted in a reduction in xylanase production by the Bacillus sp further indicating the role of YEP in stimulating biomass, perhaps via TCA cycle, using $\mathrm{C}$ sources other than xylan, resulting in reduced xylanase activity.

\section{Xylanase Production under SSF}

For xylanase production in both SSF and SmF, the optimized values of temperature, $\mathrm{pH}$, inoculum size and moisture content (in case of SSF only) were taken.

\section{On wheat bran}

Xylanase production by the bacteria in wheat bran supplemented with MSS under SSF showed maximum enzyme activity of $9.11 \mathrm{U} / \mathrm{ml}$ in $48 \mathrm{~h}$ which was comparable to the value obtained in $\mathrm{SmF}$ in $48 \mathrm{~h}$ (Tables 1and 2). Effect of addition of $1.0 \%$ xylose stimulated the enzyme synthesis producing $13.12 \mathrm{U} / \mathrm{ml}$ in $48 \mathrm{~h}$, which was more compared to that in the SmF (Fig. 5).

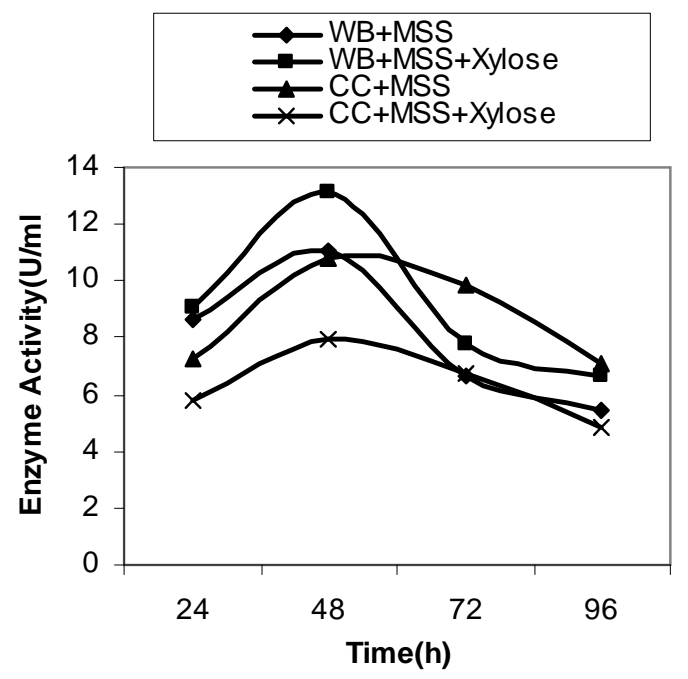

Figure 5 - Effect of xylose on xylanase production by the Bacillus sp on wheat bran and corn cob media supplemented with MSS under SSF. 
The supplementation of wheat bran with YEP however significantly improved xylanase synthesis producing $16.13 \mathrm{U} / \mathrm{ml}$ of enzyme in $48 \mathrm{~h}$ (Fig. 6). B.licheniformis A99 was found to produce 16.8 $\mathrm{U} / \mathrm{ml} \mathrm{DBB}$ on wheat bran and a mineral salt medium under SSF in $72 \mathrm{~h}$. Xylose, yeast extract, and peptone did not stimulate the enzyme production (Archana and Satyanarayanan, 1997). In the present case, xylanase production was prominently stimulated under SSF on wheat bran in the presence of YEP.This was contrary to the observations made under SmF, where YEP reduced the enzyme synthesis on wheat bran compared to MSS supplementation. It is likely that under SSF, which is basically a static-state fermentation, TCA cycle and its enzymes are not so dominant and xylan fermentation leading to xylose and subsequently hexose mono-phosphate pathway may be operating for xylose metabolism. Hence the TCA cycle and its enzymes do not repress the xylanase synthesis. The reduction in the activity of xylanase in presence of $1 \%$ xylose and YEP from 16.13 to $14.05 \mathrm{U} / \mathrm{ml}$ was also noteworthy (Fig. 6), since xylose was found to exert a stimulatory effect on xylanase synthesis on wheat bran as substrate in other cases (Tables 1 and 2). This repression might also be due to excess xylose, which inhibited the enzyme by feed back inhibition, as xylose production was anticipated from xylan degradation, as reflected by increased xylanase activity under SSF even without the addition of xylose (Table 2). Wheat bran arabinoxylan has been shown to induce maximum xylanase production in Bacillus SPS-O (Bataillon et al., 1998) compared to other inducers.

\section{On corn cob}

Xylanase production by the Bacillus sp on corn cob and MSS under SSF increased significantly up to $9.88 \mathrm{U} / \mathrm{ml}$ in $72 \mathrm{~h}$ compared to $7.11 \mathrm{U} / \mathrm{ml}$ in SmF (Tables 1and2). Xylose supplementation repressed xylanase production by $45.24 \%$ as shown by a reduction in the enzyme units from 9.88 to $7.22 \mathrm{U} / \mathrm{ml}$ (Fig. 5). The maximum enzyme activity of $7.11 \mathrm{U} / \mathrm{ml}$ under SSF on corn cob and YEP was also higher than the corresponding value of $4.52 \mathrm{U} / \mathrm{ml}$ under SmF (Tables 1and2), but lower than the corresponding values $(9.14 \mathrm{U} / \mathrm{ml})$ with MSS.

Table 2 - Comparative values of the xylanase activities of the Bacillus sp on wheat bran and corn cob under SSF.

\begin{tabular}{lcc}
\hline \multirow{2}{*}{ Medium composition } & \multicolumn{3}{c}{$\begin{array}{c}\text { Xylanase activity } \\
\text { (U/ml) }\end{array}$} \\
\cline { 2 - 3 } & Without xylose & With xylose \\
\hline WB + MSS & 9.11 & 13.12 \\
WB + YEP & 16.13 & 14.05 \\
CC + MSS & 9.88 & 7.22 \\
CC + YEP & 7.11 & 5.41 \\
\hline
\end{tabular}

*The maximum values obtained are indicated.

When mineral salt solution was used with rice bran as a moistening agent, a high yield of 3644 U/g DBB was obtained in a Bacillus sp JB-99 under SSF (Virupakshi et al., 2005). Under SSF, similar repression has been reported with malt extract, yeast extract and peptone on wheat bran by $a$ B.licheniformis A99 sp (Archana and Satyanarayanan, 1997), while yeast extract and beef extract have shown stimulatory effects on the enzyme production in a Bacillus sp on rice bran (Virupakshi et al., 2005). These findings again suggested that not only the additives, but the nature of agro-residues also played an important role in regulation of the inducible enzyme synthesis, due to differences in their chemical composition. Drop in the enzyme activity from
7.11 to $5.41 \mathrm{U} / \mathrm{ml}$ was observed in the present case, with addition of xylose on corn cob medium supplemented with YEP under SSF (Fig. 6). This may well be due to feed back repression by xylose, as corn cob is a rich source of both xylan and xylose. If xylan degradation took place more significantly, then catabolite repression by xylose was also a probability. Repression of xylanase by more than $1 \%$ xylose has been observed in a strain of A. awamori under SSF (Lemos and Junior, 2002). It was suggested that xylose had two possible effects. If xylose was added in a medium as a sole $\mathrm{C}$ source, it induced $\beta$-xylosidase biosynthesis, whereas if xylose was added to a medium containing birchwood xylan, it affected the enzyme synthesis negatively. In the present 
case, corn cob providing enough xylan to the medium, repression by xylose could be similarly explained. Repression by xylose has also been reported in a strain of Cryptococcus albidus (Beily and Petrakova, 1984).

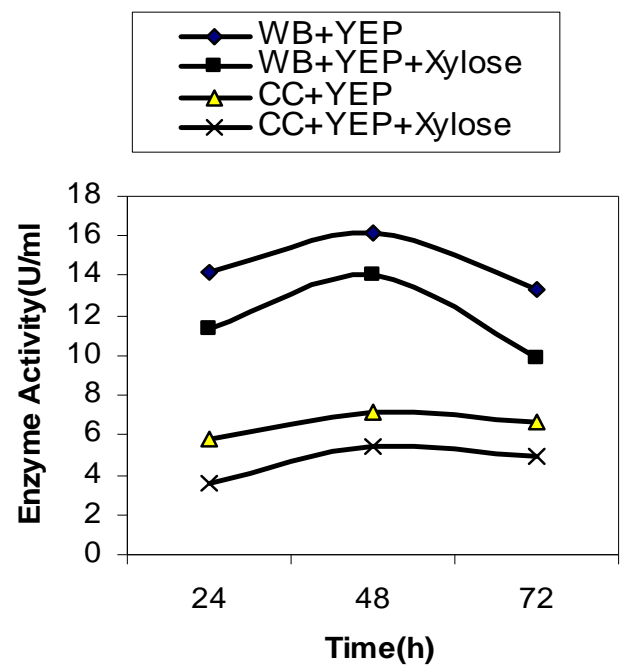

Figure 6 - Effect of xylose on xylanase production by the Bacillus sp on wheat bran and corn cob media supplemented with YEP under SSF.

It was thus, seen that maximum xylanase synthesis by the Bacillus $s p$ was observed on wheat bran medium $(16.13 \mathrm{U} / \mathrm{ml})$ when YEP was added under SSF, while corn cob supported maximum xylanase synthesis $(9.88 \mathrm{U} / \mathrm{ml})$, also under SSF, when supplementation was done with MSS (Figs. 5 and 6). In both these conditions, interestingly, addition of xylose exhibited repression. This suggested xylan degradation, stimulating xylanase synthesis and xylose production, took place in both these cases initiated by the complex $\mathrm{C}$ sources of wheat bran and corn cob. Agricultural residues have been reported to induce xylanase synthesis efficiently (Bakir et al., 2001; Santos et al., 2003; Gosh and Nanda, 1991), and additional xylose perhaps caused substrate inhibition. Alternately, feed back inhibition and catabolite repression by xylose cannot also be ruled out. Catabolite repression on synthesis of xylanase has been reported earlier (Kelley et al., 1989), while according to Liu et al. xylose did not cause any catabolite repression in the yeast, Trichosporon cutaneum (Liu et al., 1999). As xylose is converted to xylitol and then to xylulose during catabolism (Ethier et al., 1994) and as xylitol and xylulose do not induce xylanase synthesis (Liu et al., 1999), therefore stimulatory effect of xylose on xylanase synthesis does not take place, if xylose gets metabolised directly.

\section{CONCLUSIONS}

Water insoluble substrates such as corn cob and wheat bran supported higher xylanase synthesis by a Bacillus strain in SSF, as compared to SmF. Effects of xylose on the enzyme synthesis differed on these substrates in SSF and SmF, with respect to media supplementation with MSS or YEP. On wheat bran medium, xylose stimulated xylanase synthesis both in SmF and SSF, when supplemented with MSS. When YEP was the supplement, stimulation took place in SmF only, while repression by xylose was observed in SSF. On corn cob supplemented with MSS, xylanase synthesis was stimulated by xylose only in $\mathrm{SmF}$ while repression was observed in SSF. Supplementation of corn cob by YEP resulted in repression by xylose both in SmF and SSF.

\section{REFERENCES}

Anthony, T., Chandra, R.K., Rajendran, A., Gunasekaran, P.(2003), High molecular weight cellulase free xylanase from alkali-tolerant Aspergillus fumigatus ARI. Enzyme Microb. Technol., 32, 647-654. 
Archana, A., Satyanarayan, T.(1997), Xylanase production by thermophilic Bacillus licheniformis A99 in solid state fermentation. Enzyme Microb. Technol., 21, 12-17.

Bachmann, S.L., McCarthy, A.(1991), Purification and co-operative activity of enzymes constituting the xylan-degrading system of Thermomonospora fusca. Appl. Environ. Microbiol., 57, 2121-2130.

Bakir, U., Yavascaoglus, S., Guvenc, F., Ersayin, A.(2001), An endo- $\beta-1,4$ xylanase from Rhizopus oryzae: Production, partial purification and biochemical characterization. Enyzme Microb. Technol., 29, 328-334.

Bataillon, M., Cardinali, A.P.N., Duchiron, F.(1998), Production of xylanases from a newly isolated alkaliphilic thermophilic Bacillus sp. Biotechnol. Lett. 20, 1067-1071.

Beg, Q.K., Bhushan, B., Kapoor, M., Hoondal, G.S. (2002), Enhanced production of a thermostable xylanase from Streptomyces sp. QG-1l-3 and its application in biobleaching of eucalyptus kraft pulp. Enzyme Microb. Technol. 27, 459-466.

Beily, P., Petrakova, E. (1984), Novel inducers of the xylan-degrading enzyme system Cryptococcus albidus. J. Bacteriol. 160, 408-412.

Ethier, J.F., Harpin, S., Girard, G., Beaulieu, C., Dery, C.V., Brzezinski, R.(1994), Cloning of two xylanases from the isolated actinomycete Actinomadura sp. strain FC7 and characterization of the gene products. Canadian J. of Microbiol. 40, 362-368.

Fernandez, C.L.L., Rodrigez, J., Solivcri, J., CopaPatino, J.L., Perez-Leblic, M.J., Arias, M.E.(1995), The effect of culture media on the production of xylan-degrading enzymes by Streptomyces chattoogensis, UAH 23. J. Basic Microbiol. 35, 405412.

Gosh, M., Nanda, G.(1991), Immobilized Aspergillus sydowii produces xylanase. Biotechnol. Lett. 13, 807809.

Grajek, W.(1987), Production of D-xylanase by thermophilic fungi using different methods of culture. Biotechnol. Lett. 9, 353-356.

Kelley, C.T., Omahony, M.R., and Fogarty, W.M.(1989), Extracellular xylanolytic enzymes of Peacilomyces varioti. Biotechnol. Lett. 11, 885-890.

Kewalrami, N., Kamra, D.N., Lall, D., Pathak, N.N.(1988), Bioconversion of sugarcane bagasse with white rot fungi. Biotechnol. Lett. 10, 369-372.

Kohli, U., Nigam, P., Singh, D., Chaudhary, K.(2001), Thermostable, alkalophilic and cellulase free xylanase production by Thermoactinomyces thalophilus sub group C. Enzyme Microb. Technol. 28, 606-610.

Leathers, T.D., Detroy, R.W., Bothast, R.J.(1986), Induction and glucose repression of xylanase from a colour variant strain of Aurobasidium pullulans. Biotechnol. Lett. 8, 867-872.
Lemos, J.L.S., Junior, N.P.(2002), Influence of some sugars on xylanase production by Aspergillus awamori in solid state fermentation. Brazilian Archives of Biol. and Technol. 45, 431-437.

Liu, W., Lu, Y., Ma, G.(1999), Induction and glucose repression of endo- $\beta$-xylanase in the yeast Trichosporon cutaneum SL409. Proc. Biochem. 34, 67-72.

Miller, G.L.(1959), Use of dinitrosalicylic acid reagent for determination of reducing sugar. Anal. Chem. 31, 426-428.

Nascimento, R.P., Coelho, R.R.R., Marques, S., Arlves, L., Girio, F.M., Bon, E.P.S., Amaral Collaco, M.T.(2002), Production and partial characterization of xylanase from Streptomyces sp. strain AMT -3 isolated from Brazilian cerrado soil. Enzyme Microb. Technol. 31, 549-555.

Nigam, P., Singh, D.(1994), Solid state fermentation systems and their application in biotechnology. $J$. Basic Microbiol., 6, 405-423.

Paul, J., Verma, A.K.(1990), Influence of sugar on endoglucanase and $\beta$-xylanase activities of a Bacillus strain. Biotechnol. Lett. 12, 61-64.

Qinnghe, C., Ziaoyu, Y., Tiangui, N.(2004), The screening of culture condition and properties of xylanase by white rot fungus Pleurotus ostreatus. Proc. Biochem. 39, 1561-1566.

Santos, E.d., Piovan, T., Roberto, I.C., Milagres, A.M.F.(2003), Kinetics of the solid state fermentation of sugar cane bagasse by Thermoascus aurantiacus for the production of xylanase. Biotechnol. Lett. 25, 13-16.

Singh, S., Pillay, B., Prior, B.A.(2000), Thermal stability of $\beta$-xylanases produced by different Thermomyces lanuginosus strains. Enzyme Microb. Technol. 26, 502-508.

Trigo, C., Ball, A.S.(1994), Is the solubilized product from the degradation of lignocellulose by actinomycetes a precursor of humic substances? Microbiology, 140, 3145-3152.

Virupakshi, S., Babu, O.K., Gaikwad, S.R., Naik, G.R.(2005), Production of a xylanolytic enzyme by a thermo alkaliphilic Bacillus sp. JB-99 in solid state fermentation. Proc. Biochem., 40, 431-435.

Xiong, H., Turunen, 0., Pastinen, 0., Leisola, M.(2004), Improved xylanase production by Trichoderma reesei grown on L-arabinose and lactose or D-glucose mixtures. Appl. Microbial. Biotechnol., 64, 353-358.

Received: November 13, 2007; Revised: July 01, 2008; Accepted: November 06, 2008. 